\title{
Unexplained recurrent arthritis as presenting sign of hereditary autoinflammatory syndromes
}

\author{
F Zulian ${ }^{1 *}$, G Vigo ${ }^{1}$, F Vittadello ${ }^{1}$, I Ceccherini ${ }^{2}$, L Obici $^{3}$, G Martini $^{1}$ \\ From 18th Pediatric Rheumatology European Society (PReS) Congress \\ Bruges, Belgium. 14-18 September 2011
}

\section{Background}

Hereditary autoinflammatory syndromes (HAS) are a group of rare monogenic inherited conditions characterized by recurrence of symptoms of whom fever is the most frequent.

\section{Aim}

To analyze the prevalence of recurrent arthritis in a cohort of patients with HAS.

\section{Methods}

We conduced a retrospective study on 300 patients with periodic and recurrent fevers referred to a single tertiary center in 17 yrs of activity. Patients with recurrent arthritis were identified and fully investigated. On the basis of the clinical features and genetic tests, patients were divided into two groups: 275 PFAPA syndrome and 25 HAS.

\section{Results}

Patients with monogenic HAS have a later disease onset (63.4 vs 27.9) and a higher frequency of abdominal pain ( $60 \%$ vs $16.4 \%$ ), headache ( $32 \%$ vs $7.35 \%$ ) than PFAPA. Recurrent arthritis was found in 9 HAS (36\%), none in PFAPA. Interestingly, four of these 9 patients had unexplained recurrent arthritis as unique manifestation of the disease for a long time. Arthritis consisted in episodes of joint swelling, pain and limitation of movement involving, asymmetrically, large joints. In three patients most episodes occurred after infections. Attacks resolved spontaneously in few days but during disease-free intervals acute-phase reactants (CRP and SAA) were still abnormal. Genetic analysis showed heterozygous missense changes of the MEFV gene(A289V, P369S) in two

\footnotetext{
* Correspondence: zulian@pediatria.unipd.it
}

${ }^{1}$ Rheumatology Unit, Dept. of Pediatrics, University of Padua, Italy Full list of author information is available at the end of the article patients and of MVK (V250I and G336S, I268T) in the other two.

\section{Conclusions}

Unexplained recurrent arthritis may be the unique manifestation of a monogenic HAS and should be added to the list of possible differential diagnosis of the so called "palindromic arthritis".

\section{Author details}

${ }^{1}$ Rheumatology Unit, Dept. of Pediatrics, University of Padua, Italy. ${ }^{2}$ Molecular Genetics Laboratory, G. Gaslini Institute, Genova, Italy. ${ }^{3}$ Genetics Laboratory, IRCCS San Matteo, Pavia, Italy.

Published: 14 September 2011

doi:10.1186/1546-0096-9-S1-P25

Cite this article as: Zulian et al:: Unexplained recurrent arthritis as presenting sign of hereditary autoinflammatory syndromes. Pediatric Rheumatology 2011 9(Suppl 1):P25.

Submit your next manuscript to BioMed Central and take full advantage of:

- Convenient online submission

- Thorough peer review

- No space constraints or color figure charges

- Immediate publication on acceptance

- Inclusion in PubMed, CAS, Scopus and Google Scholar

- Research which is freely available for redistribution
C Biomed Central

() 2011 Zulian et al; licensee BioMed Central Ltd. This is an open access article distributed under the terms of the Creative Commons Attribution License (http://creativecommons.org/licenses/by/2.0), which permits unrestricted use, distribution, and reproduction in any medium, provided the original work is properly cited. 